\title{
Optimal size of experimental plots of papaya trees using a modified maximum curvature method
}

\author{
Mauricio dos Santos da Silva ${ }^{1 *}$ (D) Sebastião de Oliveira e Silva ${ }^{2}$ (D) \\ Sérgio Luiz Rodrigues Donato ${ }^{3}$ (D) Orlando Melo Sampaio Filho ${ }^{4}$ (D) \\ Gilmara de Melo Araújo Silva ${ }^{1}$ (D)
}

${ }^{1}$ Universidade Federal do Recôncavo da Bahia (UFRB), 44380-000, Cruz das Almas, BA, Brasil. E-mail: mauricio.engagro@gmail.com.
${ }^{*}$ Corresponding author.
${ }^{2}$ Embrapa Mandioca e Fruticultura, Cruz das Almas, BA, Brasil.
${ }^{3}$ Instituto Federal de Educação, Ciência e Tecnologia da Bahia (IF Baiano), Guanambi, BA, Brasil.
${ }^{4}$ Instituto Federal de Educação, Ciência e Tecnologia da Bahia (IF Baiano), Governador Mangabeira, BA, Brasil.

ABSTRACT: This study aimed to evaluate the optimum plot size for the papaya crop by using the modified maximum curvature method under soil and climatic conditions of the Reconcavo Baiano. The experiment comprised a uniformity test using the CNPMF-L78 strain developed by Embrapa Mandioca and Fruticultura, planted at a spacing of $3 \mathrm{~m} \times 2 \mathrm{~m}$, with 16 central rows and 22 plants per row, totaling 352 plants and an area of 2,112 $\mathrm{m}^{2}$. The following parameters were evaluated: plant height and diameter; height of insertion of the first fruits; precocity; number of commercial fruits per plant; productivity; length, diameter, weight, firmness, internal cavity diameter, pulp thickness, and soluble fruit solids. Each plant was considered as a basic unit, with an area of $6 \mathrm{~m}^{2}$, thus making up 352 basic units whose adjacent units were combined to form 11 pre-established parcel arrangements with rectangular and row formats. The optimal plot size is seven plants perpendicular to the crop rows, that is, seven rows with one plant in each row, corresponding to the area of $42 \mathrm{~m}^{2}$, considering spacing of $3 \mathrm{~m}$ between rows and $2 \mathrm{~m}$ between papaya plants in the soil and climatic conditions of the Reconcavo Baiano.

Key words: Carica papaya L., experimental precision, uniformity.

Tamanho ótimo da parcela experimental em mamoeiro pelo método da máxima curvatura modificado

RESUMO: Objetivou-se avaliar o tamanho ótimo de parcela para a cultura do mamoeiro pelo método da máxima curvatura modificado sob condições edafoclimáticas do Recôncavo Baiano. O experimento constituiu-se de um ensaio de uniformidade, utilizando a linhagem CNPMF-L78, desenvolvida pela Embrapa Mandioca e Fruticultura, plantada no espaçamento de $3 \mathrm{~m} \times 2 \mathrm{~m}$, consideradas como útil as 16 fileiras centrais com 22 plantas por fileira, totalizando 352 plantas é área de $2.112 \mathrm{~m} 2$. Foram avaliados: altura e diâmetro das plantas; altura de inserção dos primeiros frutos; precocidade de colheita; número de frutos comerciais por planta; produtividade; comprimento, diâmetro, peso, firmeza, diâmetro da cavidade interna, espessura da polpa e sólidos solúveis dos frutos. Nas avaliações, cada planta foi considerada como uma unidade básica, área de $6 \mathrm{m2}$, perfazendo assim, 352 unidades básicas, cujas as adjacentes foram combinadas de modo a formar 11 arranjos de parcelas pré-estabelecidos com formatos retangulares e em fileiras. O tamanho ótimo de parcela é de sete plantas, com sentido perpendicular às fileiras do cultivo, ou seja, sete fileiras com uma planta em cada fileira, correspondente à área de 42 m2, considerando espaçamento de 3 m entre linhas e 2 m entre plantas de mamoeiro nas condições edafoclimáticas do Recôncavo Baiano.

Palavras-chave: Carica papaya L., planejamento experimental, ensaio em branco.

\section{INTRODUCTION}

Papaya, Carica papaya L., is a fruit tree with high economic value in Brazil, being the second largest world producer of this crop (1.01 million tons), followed by India (5.94 million tons) (FAO, 2017). Bahia is the Brazilian state with the highest papaya production, followed by Espírito Santo and Ceará (IBGE, 2016).

Researchers used different methods with crops to minimize experimental error, which may occur because of several factors, such as the choice of design, plot loss, crop cycle, number of treatments, and crop treatments. The determination of plot size in different crops is one way to increase experimental accuracy, allowing for the minimization of time, optimization of resources, and guaranteeing maximum accuracy in an experiment (SILVA et al., 2012; CARGNELUTTI FILHO et al., 2018).

The modified maximum curvature method (MMCM) (MEIER \& LESSMAN, 1971) is an improved version of the maximum curvature method, which could not determine the point of maximum curvature using equations. This method consists of plotting the values of the variation coefficients of different traits against the pre-established plot sizes, obtaining a curve that represents the inverse relationship between the traits. It considers the value corresponding to the abscissa of the point of the maximum curvature as the optimal size (LESSMAN \& ATKINS, 1963). 
Thus, given the importance of papayas to Brazil and the need for further research on this species, the goal of this study was to evaluate the optimal plot size for the crop using the MMCM under the soil and climatic conditions of the Recôncavo region in the state of Bahia.

\section{MATERIALS AND METHODS}

The experiment was conducted at Embrapa Mandioca and Fruticultura, in the municipality of Cruz das Almas, Bahia, Brazil, located at $12^{\circ} 40^{\prime} 39^{\prime \prime} \mathrm{S}, 39^{\circ} 40^{\prime} 23^{\prime \prime} \mathrm{W}$, altitude $220 \mathrm{~m}$ a.s.l., average temperature of $24.5^{\circ} \mathrm{C}$, relative humidity of $82 \%$, and average annual precipitation of $1,197 \mathrm{~mm}$ (EMBRAPA, 1993).

Seeds were obtained from the CNPMF-L78 lineage from the Papaya Active Germplasm Bank (BAG-Papaya) of Embrapa. To ensure soil correction and fertilization, we followed the recommendations for the cultivation of papaya (OLIVEIRA \& COELHO, 2009), based on soil analysis of the experimental area.

First, three seeds were sown per plastic bag filled with substrate. Fifteen days after emergence, they were thinned to maintain one plant per plastic bag. After 40 days, plants were taken to the experimental area, with six plants per pit. At the beginning of flowering, only one plant was kept per pit, which had hermaphrodite inflorescence.

The design used was entirely randomized, with the study being characterized as a uniformity trial. It was conducted in a useful area formed by 16 rows with 22 plants per row with spacing of $3 \mathrm{~m} \times 2$ $\mathrm{m}$, totaling 352 plants and an area of $2,112 \mathrm{~m}^{2}$.

For evaluations, each plant was considered as a basic unit (bu), with an area of $6 \mathrm{~m}^{2}$, totaling 352 $\mathrm{bu}$, as defined from the blank trial map. Combinations resulted in 11 plot arrangements with different sizes and relative contributions (Table 1).

Eighteen different traits were evaluated, 11 morpho-agronomic characteristics of the plant and 7 were related to fruit quality: a) Plant height (PH6), (PH12), and (PH18) being the distance (m) between the soil surface and the insertion point of the youngest leaf, located at the kaolinic apex, and evaluated at 6, 12, and 18 months after planting, respectively; b) Insertion height of first fruit (IHFF) being the height (m) from the soil surface of the first functional flower (producing fruit) at the beginning of production; (c) stem diameter (SD6), (SD12), and (SD18) measured in centimeters at $20 \mathrm{~cm}$ above the surface of the soil and assessed at 6,12, and 18 months after planting, respectively; d) Precocity (PREC), evaluated in days, considering the date of the first harvest of fruit after planting; e) Number of commercial fruits per plant (NCF9) and (NCF14), being the number of commercial fruits present in each plant at 9 and 14 months after planting, respectively; f) Productivity (PROD) expressed in $\mathrm{t} \mathrm{ha}^{-1}$, and estimated by multiplying the total number of commercial fruits per plant by the average weight of the fruit per plant, considering the spacing of $3 \mathrm{~m} \times 2 \mathrm{~m}$; g) Fruit length (FL), in centimeters, for which a wooden pachymeter was used to measure the length from the base to the apex of the fruit; (h) fruit diameter (FD), expressed in centimeters, measured at the thickest part of the fruit using a wooden caliper; (i) fruit weight (FW), expressed in grams, being the fruit harvested per plant weighed on an analytical scale. Fruits were harvested when the stage of ripeness was $1 / 4$ ripe, with up to $25 \%$ yellow skin, internship 1 maturation; j) Fruit firmness (FF), expressed in $\mathrm{kg} \mathrm{cm}^{-2}$, was determined in the central region of intact ripe fruits using three readings from a penetrometer; 1) Pulp thickness (PT), expressed in centimeters, for which a pachymeter was used to determine the thickness of the pulp of larger size fruit after the fruit was cross-sectioned; m) Fruit internal cavity diameter (ICD), expressed in centimeters, where the greatest distance from the central part of each fruit was measured; n) Soluble solids (SS), expressed in ${ }^{\circ}$ Brix, was obtained using an r2mini Reichert portable digital refractometer.

Plot size was determined using the MMCM method (MEIER \& LESSMAN, 1971), defined by the main equation: $\mathrm{CV}(\mathrm{X})=\beta_{0} \mathrm{X}^{-\beta 1}$. Where: $C V(X)$ is the coefficient of variation between the plots of size $X ; X$ represents the number of grouped basic experimental units; $\beta_{0}$ and $\beta_{l}$ are parameters to be estimated using the logarithmic transformation of the function, in which the value corresponding to the maximum curvature point is estimated by the expression:

$\mathrm{x}_{0}=\left[\frac{\mathrm{a}^{2} \mathrm{~b}^{2}(2 \mathrm{~b}+1)}{(\mathrm{b}+2)}\right]^{\frac{1}{(2 \mathrm{~b}+2)}}$

Where $x_{0}$ is the value of the abscissa corresponding to the maximum curvature point and $a$ and $b$ are the estimates of the model parameters. Values corresponding to the non-integer $x_{0}$ were rounded up because it refers to a bu, i.e., a plant.

The required statistical parameters were obtained on a Microsoft Excel $^{\circledR}$ worksheet basis. Equations and graphs of the model were confirmed using SAEG software (RIBEIRO JÚNIOR, 2001).

\section{RESULTS AND DISCUSSION}

Eleven shapes were evaluated to estimate plot size. Their coefficients of variation are shown in 
Table 1 - Grouping structures of basic units (bu), arrangement, dimensions, number of plots (Xbu), and area of each plot size for the uniformity test and total relative information (RI) (Carica papaya L.).

\begin{tabular}{|c|c|c|c|c|c|}
\hline $\mathrm{N}^{\mathrm{o}}$ & Arrangement & Dimensions $(\mathrm{R} \times \mathrm{P} / \mathrm{R})$ & $\mathrm{Xbu}$ & Area $\left(\mathrm{m}^{2}\right)$ & RI $(\%)$ \\
\hline 1 & Plant & $1 \times 1$ & 1 & 6.00 & 100.00 \\
\hline 2 & Row & $2 \times 1$ & 2 & 12.00 & 99.73 \\
\hline 3 & Row & $4 \times 1$ & 4 & 24.00 & 85.93 \\
\hline 4 & Row & $8 \times 1$ & 8 & 48.00 & 78.74 \\
\hline 5 & Row & $1 \times 11$ & 11 & 66.00 & 55.57 \\
\hline 6 & Row & $16 \times 1$ & 16 & 96.00 & 64.75 \\
\hline 7 & Rectangular & $2 \times 11$ & 22 & 132.00 & 57.53 \\
\hline 8 & Rectangular & $16 \times 2$ & 32 & 192.00 & 52.97 \\
\hline 9 & Rectangular & $2 \times 22$ & 44 & 264.00 & 54.53 \\
\hline 10 & Rectangular & $8 \times 11$ & 88 & 528.00 & 45.51 \\
\hline 11 & Rectangular & $16 \times 11$ & 176 & 1056.00 & 22.85 \\
\hline
\end{tabular}

$\mathrm{R} \times \mathrm{P} / \mathrm{R}$ : Number of rows and plants per row.

Tables 2 and 3. Coefficients of variation for precocity (PREC) and number of commercial fruits per plant at 9 months (NCF9) morpho-agronomic characters ranged from $1.95 \%$ to $55.81 \%$, respectively (Table 2 ). Coefficients of variation for fruit length (FL) and fruit firmness $(\mathrm{FF})$, traits related to fruit quality, ranged from $0.48 \%$ to $19.87 \%$, respectively (Table 3 ).
Tables 2 and 3 showed that the values of the coefficients of variation usually decrease with the increase of plot size, but non-linearly. Plot arrangement influenced the experimental precision, i.e., plots with greater dimension and perpendicularly located to the plant rows, regardless of shape, usually have lower coefficients of variation. This was also

Table 2 - Estimates of coefficients of variation (\%) as a function of plot size in basic units (Xbu), for the morpho-agronomic traits of plants (Carica papaya L.).

\begin{tabular}{|c|c|c|c|c|c|c|c|c|c|c|c|c|c|}
\hline \multirow{2}{*}{ Arrangement } & \multirow{2}{*}{$\begin{array}{c}\text { Dimensions } \\
\mathrm{R} \times \mathrm{P} / \mathrm{R}\end{array}$} & \multirow[t]{2}{*}{$\mathrm{Xbu}$} & \multicolumn{11}{|c|}{------------------------------------------------------------------CV } \\
\hline & & & PH6 & PH12 & PH18 & SD6 & SD12 & SD18 & IHFF & PREC & NCF9 & NCF14 & PROD \\
\hline Plant & $1 \times 1$ & 1 & 16.06 & 12.37 & 10.33 & 29.49 & 14.21 & 11.73 & 15.21 & 11.22 & 55.81 & 38.14 & 39.89 \\
\hline Row & $2 \times 1$ & 2 & 12.52 & 9.80 & 8.26 & 22.92 & 11.51 & 9.53 & 10.77 & 7.48 & 44.4 & 29.42 & 32.58 \\
\hline Row & $4 \times 1$ & 4 & 9.88 & 7.64 & 6.70 & 17.57 & 9.33 & 7.98 & 8.20 & 5.66 & 36.97 & 24.85 & 28.64 \\
\hline Row & $8 \times 1$ & 8 & 7.14 & 5.04 & 4.92 & 12.22 & 7.44 & 6.47 & 6.06 & 4.36 & 25.74 & 19.53 & 21.39 \\
\hline Row & $1 \times 11$ & 11 & 8.01 & 7.34 & 6.34 & 12.38 & 8.40 & 7.34 & 6.15 & 3.97 & 30.68 & 26.80 & 25.79 \\
\hline Row & $16 \times 1$ & 16 & 5.62 & 4.09 & 2.68 & 8.58 & 4.31 & 3.45 & 4.72 & 3.40 & 16.69 & 13.61 & 14.20 \\
\hline Rectangular & $2 \times 11$ & 22 & 7.31 & 6.16 & 5.54 & 11.24 & 7.77 & 6.72 & 4.27 & 3.37 & 27.86 & 21.28 & 22.71 \\
\hline Rectangular & $16 \times 2$ & 32 & 4.44 & 3.74 & 2.21 & 7.04 & 3.83 & 2.75 & 3.69 & 3.02 & 15.48 & 12.72 & 13.67 \\
\hline Rectangular & $2 \times 22$ & 44 & 4.88 & 4.56 & 4.81 & 7.13 & 6.70 & 6.01 & 3.10 & 1.95 & 25.68 & 19.20 & 20.73 \\
\hline Rectangular & $8 \times 11$ & 88 & 6.11 & 4.11 & 4.34 & 9.47 & 6.79 & 5.82 & 2.40 & 2.97 & 22.50 & 15.74 & 18.75 \\
\hline Rectangular & $16 \times 11$ & 176 & 5.62 & 4.00 & 2.02 & 8.22 & 3.68 & 2.18 & 2.40 & 3.19 & 12.32 & 9.56 & 10.93 \\
\hline
\end{tabular}

$\mathrm{R} \times \mathrm{P} / \mathrm{R}$ : Number of rows plants per row.

PH6, PH12, and PH18: Plant height at 6, 12, and 18 months, respectively; SD6, SD12, and SD18: Plant stem diameter at 6, 12, and 18 months, respectively; IHFF: Insertion height of the first fruit; PREC: Precocity; NCF9 and NCF14: Number of commercial fruits per plant at 9 and 14 months, respectively; PROD: Productivity. 
Table 3. - Estimates of coefficients of variation (\%) as a function of plot size in basic units (Xbu) for traits related to fruit quality (Carica papaya L.).

\begin{tabular}{|c|c|c|c|c|c|c|c|c|c|}
\hline \multirow[t]{2}{*}{ Arrangement } & \multirow{2}{*}{$\begin{array}{c}\text { Dimensions } \\
\mathrm{R} \times \mathrm{P} / \mathrm{R}\end{array}$} & \multirow[t]{2}{*}{$\mathrm{Xbu}$} & \multicolumn{7}{|c|}{ 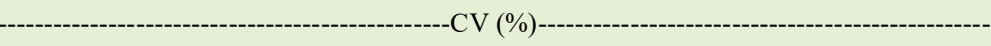 } \\
\hline & & & FD & FL & FW & $\mathrm{FF}$ & $\mathrm{PT}$ & ICD & SS \\
\hline Plant & $1 \times 1$ & 1 & 6.63 & 6.15 & 17.14 & 19.87 & 11.53 & 9.38 & 5.50 \\
\hline Row & $2 \times 1$ & 2 & 4.88 & 4.37 & 12.40 & 14.14 & 8.93 & 6.73 & 3.99 \\
\hline Row & $4 \times 1$ & 4 & 3.46 & 3.18 & 8.89 & 10.31 & 7.07 & 4.55 & 2.81 \\
\hline Row & $8 \times 1$ & 8 & 2.67 & 2.60 & 6.99 & 7.85 & 5.31 & 3.16 & 1.98 \\
\hline Row & $1 \times 11$ & 11 & 2.66 & 2.47 & 7.34 & 7.73 & 5.45 & 2.93 & 2.12 \\
\hline Row & $16 \times 1$ & 16 & 2.40 & 2.03 & 5.37 & 5.45 & 4.21 & 2.68 & 1.23 \\
\hline Rectangular & $2 \times 11$ & 22 & 2.32 & 1.92 & 6.32 & 6.21 & 4.88 & 2.31 & 1.52 \\
\hline Rectangular & $16 \times 2$ & 32 & 2.03 & 1.74 & 4.32 & 4.65 & 3.68 & 1.70 & 0.94 \\
\hline Rectangular & $2 \times 22$ & 44 & 1.16 & 1.68 & 4.96 & 4.29 & 3.78 & 1.91 & 1.10 \\
\hline Rectangular & $8 \times 11$ & 88 & 1.88 & 1.38 & 4.92 & 4.68 & 4.41 & 1.30 & 1.08 \\
\hline Rectangular & $16 \times 11$ & 176 & 2.12 & 0.48 & 3.76 & 5.10 & 4.06 & 0.89 & 0.76 \\
\hline
\end{tabular}

$\mathrm{R} \times \mathrm{P} / \mathrm{R}:$ Number of rows and plants per row.

FD: Fruit diameter; FL: Fruit length; FW: Fruit weight; FF: Fruit firmness; PT: Pulp thickness; ICD: Fruit internal cavity diameter; SS Soluble solids.

reported by DONATO et al. (2008) and BRUM et al. (2016), who calculated the optimal plot size in bananas and broccoli, respectively, observed a decrease in $\mathrm{CV}$ with a differentiated rate of decrease and an increase in plot size.

Figure 1 shows that the estimates of optimal plot size $\left(x_{0}\right)$ for the morpho-agronomic traits ranged from $x_{0}=1.64 \mathrm{bu}$, approximately $x_{0}=2 \mathrm{bu}$ for the precocity character (PREC) to $x_{0}=6.46 \mathrm{bu}(7 \mathrm{bu})$ for the number of commercial fruits per plant at nine months (NCF9) character.

Figure 1 shows that the coefficient of determination of the morpho-agronomic traits ranged from $r^{2}=0.6082$ to $r^{2}=0.9817$, corresponding to stem diameter at 18 months and insertion height of the first fruits (IHFF) characters, respectively. Coefficient of determination of the model was not directly related to the optimal plot size, as can be seen in the number of commercial fruits per plant at 9 months (NFC9) trait, which had greater optimal plot size, 6.46 bu ( 7 $\mathrm{bu}$ ) and $\mathrm{r}^{2}=0.7425$, compared to that reported for the stem diameter at 18 months $\left(\mathrm{r}^{2}=0.6082\right)$ trait, with an optimal plot size of $2.01 \mathrm{bu}(3 \mathrm{bu})$.

In the traits related to fruit quality (Figure 2 ), the estimates of optimal plot size $\left(x_{0}\right)$ ranged from $1.09 \mathrm{bu}$ for the fruit diameter character (FD) to $x_{0}=$ 2.83 for the fruit firmness character (FF). Coefficients of determination of the equations ranged from $\mathrm{r}^{2}=$
0.7402 to $r^{2}=0.9877$, corresponding to the fruit diameter (FD) and fruit internal cavity diameter (ICD) traits, respectively.

Using this method, one should consider the optimal size the largest plot size determined for the traits evaluated because the variables observed in the study were usually evaluated together. Thus, the largest size for a characteristic with greater variability was selected; in this case, it was NCF9, the number of commercial fruits per plant at 9 months, whose value was 7 bu (Figure 1). Using this method, all the analyzed traits were addressed. Moreover, it was justifiable to adopt this procedure because the MMCM, despite its simplicity and determination by equations, tends to estimate smaller plot sizes as compared to that of other methods (DONATO et al., 2008; 2018).

However, tables 1 and 2 show that plots in rows located perpendicular to the rows of the plants had higher relative information (RI\%) and lower coefficients of variation $(\mathrm{CV} \%)$, compared to the rectangular plots or plants in rows. The shape of the plot, expressed by the relationship between its length and width influenced experimental precision, which could be determined by analyzing the behavior of the $\mathrm{CV} \%$ and the relative information from the different forms of plots with similar sizes (Tables 1 and 2). Plots with greater dimension and located perpendicular to 


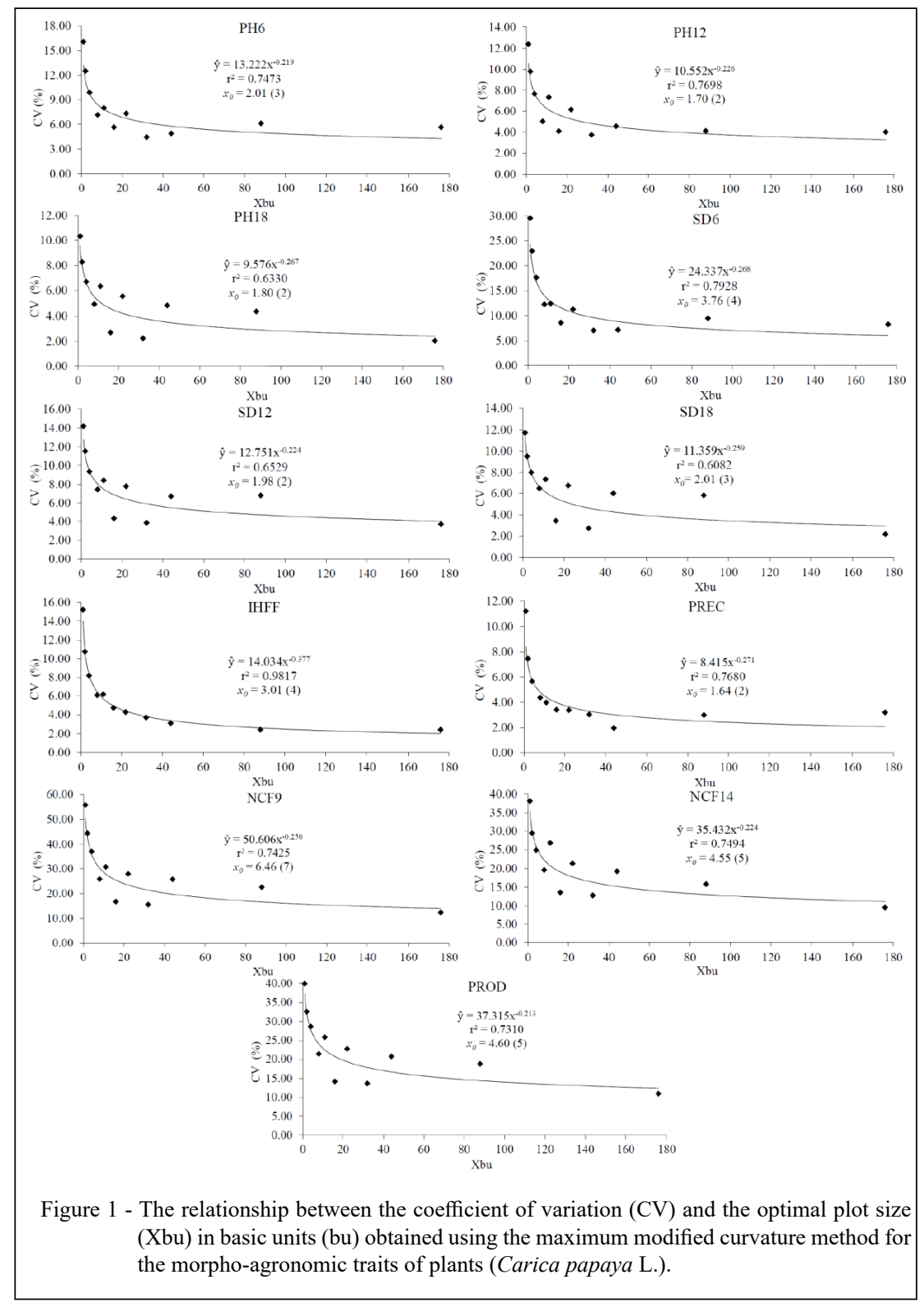

the rows of plants, regardless of the shape, being in rows or rectangular, usually had higher RI (Table 1) and lower $\mathrm{CV} \%$ (Table 2); thus, they showed a decrease in variability in the perpendicular direction to plant rows.

For example, plots in rows with eight plants, with sizes similar to the one determined by equations using the maximum modified curvature method, located perpendicular to the rows of plants ( 8 rows $\times 1$ plant per row) had an RI of $78.74 \%$, whereas larger plots with 11 plants in the row direction (1 row $\times 11$ plants per row) had a RI of 55.57\% (Table 1 ).
Considering traits with greater variability, NCF9 had a CV for $8 \times 1$ plots of $25.74 \%$ and for $1 \times 11$ plots was $30.68 \%$ (Table 2 ), exhibiting an increase in variability with the direction of the row. Thus, the optimal plot size should be seven plants perpendicular to the crop rows, i.e., seven rows with one plant in each row.

These results differed from those of SCHMILDT et al. (2016), who conducted a field experiment evaluating the THB and Golden varieties of papaya and the F1 of Tainung and Uenf/Caliman 01 hybrids using a similar methodology and reported 6 bu and $4 \mathrm{bu}$, corresponding to the morpho-agronomic 


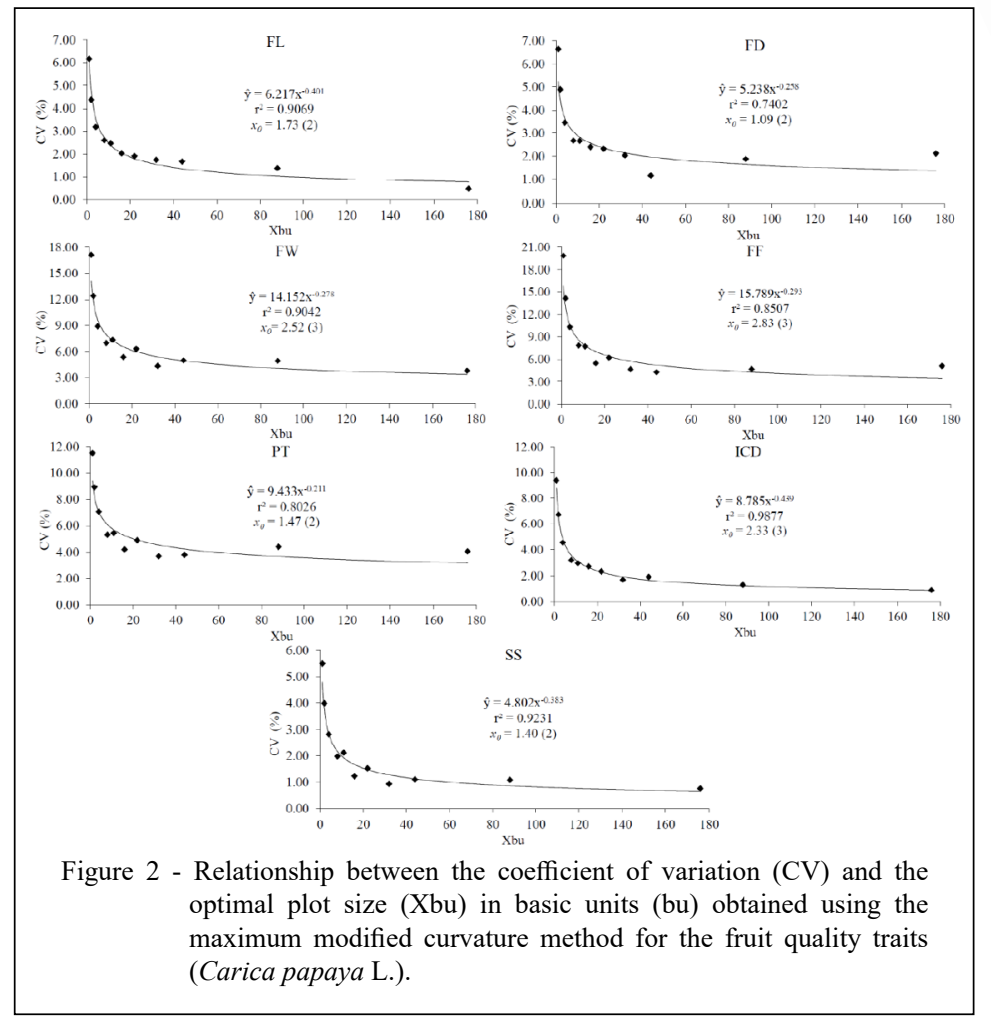

traits and fruit quality. They concluded that the optimal plot size was 6 bu, i.e., six plants per plot. Different results can be explained by the differences between genetic materials, evaluation periods, crop management, and soil and climate conditions of the study area (BOER et al., 2008).

According to PEIXOTO et al. (2011), estimated plot sizes should not be considered the maximum optimal plot sizes, but the minimum, because if the necessary resources are available, it is up to the researcher to use a plot size above the minimum value.

\section{CONCLUSION}

The optimum plot size is seven plants located perpendicular to the rows of the crop, i.e., seven rows with one plant in each row, corresponding to an area of $42 \mathrm{~m}^{2}$, and spacing of $3 \mathrm{~m}$ between rows and $2 \mathrm{~m}$ between papaya plants under the soil and edaphoclimatic conditions of the Recôncavo Baiano.

\section{ACKNOWLEDGEMENTS}

The Higher Education Personnel Improvement Coordination (CAPES), Brazil - Financial Code 2015/1542915. Embrapa Mandioca and Fruticultura and the Pró-Reitoria de
Pesquisa, Pós-Graduação, Criação e Inovação, Universidade Federal do Recôncavo da Bahia (PPGCI/UFRB).

\section{DECLARATION OF CONFLICT OF INTERESTS}

The authors declare no conflict of interest. The founding sponsors had no role in the design of the study; in the collection, analyses, or interpretation of data; in the writing of the manuscript, and in the decision to publish the results.

\section{AUTHORS' CONTRIBUTIONS}

The authors contributed equally to the manuscript.

\section{REFERENCES}

BOER, C. A.; et al., Biomass, decomposition and soil cover by residues of three plant species in central- western Brazil. Rev. Bras. Ciênc. Solo, v.32, p.843-851, 2008. Available from: $\quad<\mathrm{http}$ ://www.scielo.br/scielo.php?script=sci_arttext\&pid $=$ S0100-06832008000200038 $>$. Accessed: Aug. 07, 2019. doi: $10.1590 / \mathrm{S} 0100-06832008000200038$.

BRUM, B.; et al., Optimum plot size for evaluating the mass and diameter of broccoli heads. Cienc. Rural, v.46, n.3, p.447463, 2016. Available from: <http://www.scielo.br/scielo. php? script $=$ sci_arttext $\&$ pid $=$ S0103-84782016000300447\&ln $\mathrm{g}=\mathrm{pt \&}$ tlng $=\mathrm{pt}>$. Accessed: Aug. 07, 2019. doi: 10.1590/0103$8478 \mathrm{cr} 20150236$. 
CARGNELUTTI FILHO, A.; et al., Sample Size for Height and Diameter Evaluation of Timbauva Plants. Floresta e Ambiente, v. 25, n. 1, p. 1-9, 2018. Available from: <http://www.scielo.br/scielo. php?script $=$ sci_arttext\&pid $=$ S2179-80872018000100110\&ln $\mathrm{g}=$ pt\&tlng=pt $>$. Accessed: Aug. 07, 2019. doi: 10.1590/21798087.121314 .

EMBRAPA. National Land Survey and Conservation Service. Detailed survey of the soils of the National Center for Cassava Research and Tropical Fruit. Cruz das Almas: Embrapa-CNPMF, 126p, 1993. (Embrapa-CNPMF. Boletim de Pesquisa, 7).

DONATO, S. L. R.; et al., Estimates of plot size for the evaluation of phenotipics descriptors in banana. Pesq. agropec. bras., v.43, n.8, p.957-969, 2008. Available from: <http://www.scielo.br/ scielo.php?script $=$ sci_arttext\&pid $=$ S0100-204X2008000800003\& $\operatorname{lng}=$ pt\&tlng $=$ pt $>$. Accessed: Aug. 07, 2019. doi: 10.1590/S0100204X2008000800003.

DONATO, S. L. R.; et al., Experimental planning for the evaluation of phenotipic descriptors in banana. Rev. Bras. Frutic., v.40, n.5, p.1-13, 2018. Available from: $<$ http://www.scielo.br/scielo.php?script $=$ sci arttext\&pid=S0100-29452018000500501\&lng=en\&tlng=en $>$. Accessed: Aug. 07, 2019. doi.org/10.1590/0100-29452018962.

FAO - Food and Agriculture Organization of the United Nations. Production. 2017. Available from: <http://www.fao.org/faostat/ en/\#data/QC>. Accessed: Dec. 26, 2018.

IBGE - Brazilian Institute of Geography and Statistics. Municipal Agricultural Production, 2016. Available from: <https://www. ibge.gov.br/estatisticas-novoportal/economicas/agricultura-epecuaria.html>. Accessed: Dec. 26, 2018.

LESSMAN, K. J.; ATKINS, R. E. Optimum plot size and relative efficiency of lattice designs for grain sorghum yield tests. Crop
Science, v.3, n.5, p.477-481, 1963. Available from: <https:// dl.sciencesocieties.org/publications/cs/abstracts/3/6/CS00300604 77 ?access $=0 \&$ view $=$ article $>$. Accessed: Aug. 07, 2019.

MEIER, V. D.; LESSMAN, K. J. Estimation of optimum field plot shape and size for testing yield in Crambe abyssinica Hochst. Crop Science, v.11, n.5, p.648-650, 1971. Available from: $<$ https://dl.sciencesocieties.org/publications/cs/abstracts/11/5/ CS0110050648>. Accessed: Aug. 07, 2019. doi: 10.2135/cropsci 1971.0011183X001100050013x.

PEIXOTO, A. P. B.; FARIA, G. A.; MORAIS, A. R. Using of regression plateau models in estimation of plot sizes for experiments with passion fruit. Cienc. Rural, v.41, n.11, p.19071913, 2011. Available from: <http://www.scielo.br/scielo. php?script $=$ sci_arttext\&pid $=$ S0103-84782011001100010\&lng $=$ pt\&tlng=pt $>$ Accessed: ago. 07, 2019. doi.org/10.1590/S010384782011001100010 .

RIBEIRO JÚNIOR, J. I. Statistical analysis in SAEG (Statistical Analysis and Statistical System). Viçosa, MG: Ed. Folha de Viçosa, 300p., 2001.

SCHMILDT, E. R.; et al., Optimum plot size and number of replications in papaya field experiment. Rev. Bras. Frutic., v.38, n.2, e-373, p.1-9, 2016. Available from: <http://www.scielo.br/scielo. php?script $=$ sci_arttext\&pid $=$ S0100-29452016000200603\&lng =en\&tlng=en>. Accessed: Aug. 07, 2019. doi: 10.1590/010029452016373.

SILVA, L. F. de O.; et al., Optimal plot size for experiments with radish. Rev. Ceres, v. 59, n. 5, p. 624-629, 2012. Available from: $<$ http://www.scielo.br/scielo.php?script=sci_arttext\&pid=S0034737X2012000500007\&lng=pt\&tlng=pt $>$. Accessed: Aug. 07, 2019. doi: 10.1590/S0034-737X2012000500007. 